DR PETER HOAR is a senior lecturer in radio at Auckland University of Technology, with interest in media and war.

\section{Opening shot over the parapet}

The great adventure ends: New Zealand and France on the Western Front, edited by Nathalie Phillippe, Chris Puglsey, John Crawford \& Matthias Strohn, Christchurch: John Douglas Publishing, 2013. 424 pp. ISBN 9780987666581.

$\mathrm{T}$ HIS volume is another shot in the bombardment of books about the Great War that marks the 2014 centenary of the start of the 'war to end all wars'. This literary big push includes novels, graphic novels, histories, biographies, memoirs and diaries written for specialists and the general public. An early publication to pop over the parapet, this collection offers a diverse set of articles that highlight some not so well-known aspects of New Zealand's involvement on the Western Front during the 1914-18 war. The varied articles in The Great Adventure Ends reflect both the book's origins in a conference and the variety of ways in which World War I is written about. The conference was in 2008 at the French town of Le

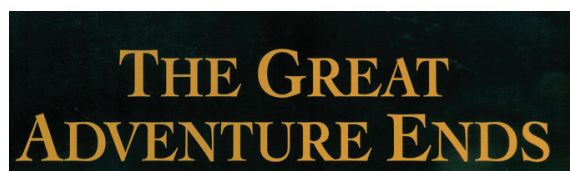

New Zealand and France on the Western Front

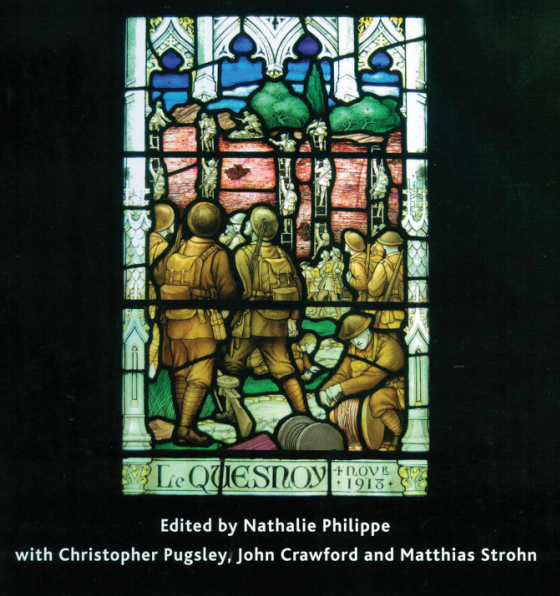

Quesnoy. This name is well-known in New Zealand military circles for its capture from the occupying German army by the New Zealand Rifle Brigade during November 1918 when the town's medieval walls were scaled by troops using ladders. This book is a result of the links between the people of Le Quesnoy and New Zealand.

The book's authors hail from France, Germany and New Zealand and provide a range of perspectives on both the battle of Le Quesnoy and the war in general. One of the book's points of interest is this broad view that ranges from discussions of the writers Katherine Mansfield (Gerri 
Kimber) and Guillaume Apollinaire (Paul Raoult) to accounts of the often dismal experiences of returned soldiers in New Zealand (Nigel Murphy). Non-academic writers such as Sue Haxton and David Blyth contribute stories about their relatives' experiences during the war and the battle of Le Quesnoy in particular. These individual, personal stories provide a good balance to the sort of military historical narratives given by writers such as Christopher Puglsey, Matthias Strohn and John Crawford. One of the livelier articles is by amateur historian Richard Stowers and concerns the exploits of Malcolm McGregor, a New Zealand pilot who flew with the Royal Flying Corps from April 1917 until the end of the war.

Along with Stowers, other writers recover aspects of the New Zealand experience of the war that are often overlooked. Ross Blair's fascinating discussion of the New Zealand Medical Corps links facial reconstruction with the foundation of plastic surgery. The French town of Arras may become another stopover for Great War tourist New Zealanders who have read Anthony Byledbał's account of the massive underground complex built below the town by the New Zealand Engineers Tunnelling Company. This article includes a somewhat patronis- ing section about the Māori soldiers who served in France as Pioneers which unfortunately concludes with a blaring and clichéd restatement of the 'one people' mythology, rather than a more nuanced take on the Māori experience of the war.

For this reader, the non-military history contributions to the book are the more interesting ones. The articles by Nathalie Philippe on civilian life in occupied France and Arnaud Waquet's on the 'diffusion of football and rugby in France' both offer fascinating social and cultural insights into life and experience beyond the battlefields. Allison Oosterman's careful examination of New Zealand war correspondent Malcolm Ross's unsuccessful work in France discusses the roles of journalism and the mass media during the first mass war in history and reminds us that for most people, the 1914-18 war was experienced through newspapers and films rather than through direct experience of the battlefields. Another article that examines the mediation of the war is Caroline Lord's work on the official war artists of the New Zealand Division. The reproduced paintings handsomely show the high standard of work by the artists Nugent Welch and George Edmund Butler. As Lord points out, the works produced by these and other New Zealand artists 
during the war have been neglected and forgotten. I hope her research goes some way to redressing this.

Along with the reproduced paintings, the book contains a host of well chosen photographs, illustrations and maps many of which are new to me. The illustrations are relevant and complement the text usefully rather than just being decorative eye candy. There are separate indexes for people, places and army units. One index that also included concepts as well as things and places would be more convenient. Overall, this is a rich collection of pieces based around the activities of the New Zealand Division in France during the First World War. Both academics and lay readers would find much of interest in the wide range of topics and approaches although I would have preferred a little less military and more social and cultural history. But it's an impressive enough salvo. 